\title{
STUDENT BUSINESS CENTER AS A MEANS OF DEVELOPING ENTREPRENEURSHIP CAPACITY FOR STUDENTS
}

\author{
Devi Rachmasari* \\ devi@staff.ubaya.ac.id, devi.rachmasari.2@gmail.com
}

\begin{abstract}
Entrepreneurs obviously play significant role in the growth of economics as it can be seen in the industrial countries which have more than 10\% entrepreneurs of their population. Indeed, the role of universities in preparing the society, especially their graduation to be self-employed, to be an entrepreneur is surely substantial. Entrepreneurship education is the answer in maximizing students' capacity on knowledge as well as skill to be entrepreneurs. Many studies indicate the positive impact of entrepreneurship education. This paper will discuss entrepreneurship education in Politeknik Ubaya especially through Student Business Center, a place where students are able to practice what they have learned in the classroom.
\end{abstract}

Keywords: entrepreneurship, entrepreneurship education, capacity building.

\section{Introduction}

The role of entrepreneurship on the economic growth is significant since it can be identified in industrial countries such as United Sates of America, Japan and Singapore. USA and Japan have more than $10 \%$ entrepreneurs of the population, while Singapore has $7 \%$ entrepreneurs. It is indeed as explained by David McCleiland as well as Ciputra that a nation needs to have at least $2 \%$ of entrepreneurs to make the economic growth. It means that Indonesia needs to have about 4.8 million entrepreneurs.

It can be learned that most universities in Europe as well as USA, include entrepreneurships in almost of their courses, while in Japan and Singapore, entrepreneurship is taught at least two semesters. Thus, it can be seen that the role of universities in building entrepreneurship capacity for their graduation is essential. University can contribute to equip students with entrepreneurship mindset and skill, soft skill as well as hard skill to be young entrepreneurs who are ready to start up their own business.

This article is going to discuss the practice and implementation of entrepreneurship education in Politeknik Ubaya. The discussion will focus on the practice of entrepreneurship knowledge and skill that students got in the classroom to the real life through Student Business Centre.

* The author is a lecturer at Business English Study Program, Politeknik Ubaya, Surabaya. 


\section{Literature Review}

\section{Entrepreneurship}

It is a bit hard to change student mindset to be an entrepreneur since it involves creative thinking as well innovative idea to find the problem in the market and to solve it by creating competitive value on the product or service so that it suits the market need.

It is as described by Eze (2011) that "entrepreneurship education therefore is a process of changing people's mindset towards applying creative thinking and innovative approach to solve identifiable problems, or improving systems in which they find themselves.

Moreover, Hisrich (2002) added that in creating value, one needs to spend time and put effort, as well financial, psychological and social risk, and at the end it give personal satisfaction and monetary result.

\section{Capacity Building}

Students'competence need to be maximized, their capacity on entrepreneurship need to be built by equipping them with both soft skill and hard skill. Azikiwe (2006) in Nwazor (2012) described capacity building as "the process by which an individual, irrespective of sex, are equipped with skills and knowledge they need to perform effectively and efficiently in their different calling."

Moreover, a university is the door for students to maximize their capacity and to be ready in the society. The university facilitates students with knowledge, skill that will be needed after they graduate and enter the real working life in the society.

\section{Entrepreneurship Education}

Drucker in Kuratko (2005) said that entrepreneurship is a discipline, thus it can be learned. Moreover that idea was supported by Gorman, Hanlon and King in Kuratko (2005) that most of the empirical studies showed that entrepreneurship can be taught or at least encouraged by entrepreneurship education.

Entrepreneurship education itself, as said by Zhou and Xu (2012), was introduced by the United States in 1940s. Then entrepreneurship education was adopted in many countries for fostering job creation. Later on UNESCO World Conference understood its value and suggested to cultivate entrepreneurship skill in higher education.

Furthermore, according to Schulte in Fitriati (2015), regarding entrepreneurship education, university actually has three significant roles as follow:

1. Facilitator of entrepreneurship culture University can motivate, support as well as facilitate entrepreneurship spirit and provide supportive entrepreneurial environment to students. Thus it will create and maintain entrepreneurship culture among students.

2. Mediator of entrepreneurship skill

The entrepreneurial knowledge and skill learned by students in the classroom hopefully can be transferred, implemented, modified by the students in their future life after graduation.

3. Locomotive of local business development

University can initiate networking with other parties to boost the emerge of start up business as well as creating job opportunities.

Moreover Maritz and Brown did mapping of common method used in entrepreneurship education based on some studies as below (Table 1.): 
Table 1. Entrepreneurship education based on some studies

\begin{tabular}{|c|l|l|}
\hline 1 & Business Plan & $\begin{array}{l}\text { The business plan can be done individually or in a group. The } \\
\text { business plan competition is common and ideally based on good } \\
\text { feasibility. The indicator is start up a business. }\end{array}$ \\
\hline 2 & Business Simulation & $\begin{array}{l}\text { Students practice on a real or virtual business. It is also possible } \\
\text { by case studies. }\end{array}$ \\
\hline 3 & Case Studies & Presentation and case studies of real enterprise or entrepreneurs \\
\hline 4 & Classroom Lecture & $\begin{array}{l}\text { Lecturing, including utilizing textbook that discuss about } \\
\text { marketing, accounting, financing and strategy }\end{array}$ \\
\hline 5 & Clubs and networks & $\begin{array}{l}\text { Clubs and networks are created in order to discuss } \\
\text { entrepreneurships issues }\end{array}$ \\
\hline 7 & Communication training & $\begin{array}{l}\text { The skill of presentation, including power point presentation, } \\
\text { public speaking, writing, etc }\end{array}$ \\
\hline 8 & Games and Competitions & $\begin{array}{l}\text { It is conducted to decide whether the business plan is worth } \\
\text { enough to be implemented as start up business }\end{array}$ \\
\hline 9 & Guest lecturers & Business plan competition, software program \\
\hline 10 & Mentor & $\begin{array}{l}\text { Usually from local business community or someone who are } \\
\text { experts in specific topic such as accounting, marketing etc. }\end{array}$ \\
\hline 11 & $\begin{array}{l}\text { Placements with small medium } \\
\text { enterprise / consulting project }\end{array}$ & $\begin{array}{l}\text { Coaching on business idea, business plan or other business topics. } \\
\text { The mentors usually are teacher, businessman, entrepreneurs or } \\
\text { expert. }\end{array}$ \\
\hline 12 & $\begin{array}{l}\text { Short placement at small medium enterprise / consulting project } \\
\text { hopefully is able to give description for students aboutthe business } \\
\text { itself }\end{array}$ \\
\hline 13 & Setting up a business & $\begin{array}{l}\text { Students work in a short period to get experience about a } \\
\text { business } \\
\text { The business is managed in a program such as business incubator }\end{array}$ \\
\hline 15 & Study visit & $\begin{array}{l}\text { Students visita a company related to entrepreneurship to get used } \\
\text { to daily operation of the company }\end{array}$ \\
\hline It means Group discussion or project based work \\
\hline 7 training
\end{tabular}

Meanwhile, Fitriati (2012) described that entrepreneurship education in some leading universities in Indonesia have the uniqueness of added value of local wisdom on the basis of each vision, mission as well as the purpose of each of the universities.

A lot of universities in Indonesia apply method and strategy to increase entrepreneurships spirit and comprehension for their students. Entrepreneurship is taught not only as a course but the universities also provide other facilities as follows:

\section{Entrepreneurship Priority}

A university starts to be aware of its role to improve students' capacity on entrepreneurship. It is started from priority entrepreneurship matters. En-trepreneurship is not merely taught as a subject course, but it considers many things related to it, such as the curricula, teaching methodology, students' exposure to more knowledge, profound understanding and enterprise experience.

\section{Entrepreneurship Center}

Entrepreneurship center will hold seminar, workshop, talk show, entrepreneurship expo, and entrepreneurship competition in order to enrich students' in- 
sight and experience by inviting external speaker or practitioners to share their best practice to students. Hopefully it can open and raise students' interest to start their own business. Sometimes, a university holds entrepreneurship expo to exhibit students' product and test the market. It also holds competition to attract students to implement their concept of business idea and then it provides the winner with some capital for their business.

3. Coaching to Support Students Participation on Students Entrepreneurship Program (Program Mahasiswa Wirausaha/ PMW)

The Program held by Directorate of Higher Education is a competition of business plan for students. The winner will be awarded some amount of money as subsidy for their capital to implement students' business idea. It is a competitive and prestigious contest. A university needs to prepare and to coach their students well to participate in this competition.

4. Coaching to Support Students Participation on Other Entrepreneurship Competition Held by Company

Lots of companies, one of them is PT.Bank Mandiri Tbk, hold entrepreneurship competition for students as one of their social corporate responsibility (CSR) projects.. The winners will get some money to support their capital.

\section{Discussion}

\section{Entrepreneurship Education at Politeknik Ubaya}

Politeknik Ubaya is one of the university which concerns on the significant of entrepreneurship for students. One of the strategic planning of Politeknik Ubaya is having graduations that have entrepreneurship spirit to support business and industry.

Here, entrepreneurship is taught as a subject for a semester. While for taxation study program students, they get entrepreneurship subject for two semesters.

The curriculum design as well as teaching method are also noticed. Students are asked to do observation on small business to comprehend best practice of entrepreneurship on daily activity basis from the real condition. Then they should make a report on it. Based on that, completed with the subject taught in the classroom, they learn to create their business idea, analyze the feasibility and make a business canvas model, kind of short description of business plan which is written in one sheet of paper.

\section{Student Business Centre (SBC)}

Some studies show that university should mix entrepreneurship education for students not only through classroom teaching, but also other teaching method. Ronstadt in Kuratko (2005) mentioned that students need to be prepared to an unstructured situation, uncertain nature of entrepreneurial experience. John \& English (2004) in Kuttim, Kallaste, Venesaar and Kiis (2014) described that a mixture of action-oriented teaching which encourages experiential learning, problem solving, project-based learning, creativity and is supportive of peer evaluation is the best way to give enterprising skill and behavior. Moreover Fayolle (2007) stated that designing an integrated and comprehensive curriculum of entrepreneurship education so that be able to facilitate students' need is challenging for university.

Based on those above explanation, Politeknik Ubaya tries to do the best by providing a facility to students in order they can practice entrepreneurial skill, find their business idea and get it real. The facility given to students to implement their business idea called Student Business Centre (henceforth 
is called $\mathrm{SBC}$ ). SBC is a stall together with some little capital for students to implement their business idea. Students interested in developing their entrepreneurial skill and want to practice their knowledge are able to gather and make a group to manage SBC.

Actually, students' attention on entrepreneurship is quite high. Unfortunately they are lack of the soul of entrepreneurship. Students tend to do more selling practice than entrepreneurship. It seems it is not clear enough for them the difference of selling and entrepreneurship. They sell varies goods to their friends such as snack, beverage, fashions, cosmetics, SIM card / top up credit for mobile, etc. Most of the students sell the product as they want to sell that certain goods, for fun, and more reselling than production. It is a pity that they do not start with market survey, as taught in the class, before they decide to implement the business idea.

Furthermore, they do the marketing by word of mouth, to their friends only, they do poor promotion. Students just rely on their idea and put it into action without any innovation on the goods they sold and any creativity in the way they market their product. They do it for fun in a short time, for the purpose of earning pocket money. These ways of implementing their business idea happen in SBC. From the observation on the group who run SBC, the writer found the following conditions:

1. No specific motivation to run the SBC

The group just do it, let it flow. Thus they run Student Business Centre with no specific target, no specific action.

2. Poor understanding of entrepreneurship versus selling

Students just sell the product, even they do reselling. They do not do market survey and moreover, they do not give touch of innovation to their business idea.

3. Lack of understanding of a business model
The group who run SBS is they are who interested to run it. Sometimes they are mixture of students who got entrepreneurship subject and who have not got the subject yet. Thus, combined with condition number one and two, it just makes worst. The things that they should pay attention but they miss them, are:

a. Value propositions of the product

The groups tend to minimize the risk of failure, so they sell popular product. Of course at earlier time, it was sold out. Later on, customers will get bored. Then, the sales decrease.

Indeed, the groups need to survey the market and offer something different / something new or modified product / service to attract customers. They must give value to the product they offer.

b. Channels of marketing

As explained above, students tend to do word of mouth marketing and to customers who directly come to the booth. Meanwhile, SBC opens only during class break and after class is finished. Therefore, the opportunity to get or attract more customers is limited and the result is almost one. In other words, there is no progress.

c. Customer relationship to maintain customers' loyalty

It seems that students have limited idea about how to maintain their customers.

d. Human capital

The group tends to choose their close friend as their partner without considering the job description needed to run the business. Therefore, every group is lack of good administration / management.

e. Revenue streams

The revenue mostly comes from selling the product. Actually there are many 
other students who are not part of SBC who sell goods. It is good opportunity to ask them to do consignment with SBC to generate money. Other that SBC can offer are to be snack supplier for Politeknik Ubaya meeting.

\section{Conclusion}

The existence of Student Business Centre offers students with good opportunity to implement entrepreneurial knowledge and skill they learned in the classroom and get real unstructured experience of entrepreneurship life.

Unfortunately the writer found that it is not enough to maximize students' entrepreneurship capacity. There are some shortages found: no specific motivation to run SBC, poor understanding of entrepreneurship versus selling, and lack of understanding of a business plan.

Responding to the above shortages, the writer proposes some solutions to improve Student Business Centre so that it can maximize students' capacity building on entrepreneurship. The writer considers that Politeknik Ubaya should facilitate:

1. Entrepreneurial group for students and alumni

It will be the best place for students to share knowledge, skill, business idea, best practice as well as problems within members.

SBC is actually advised by a lecturer. Sometimes the result of discussion with the advisor is not implemented by the groups. Furthermore, if there is any friction among member of the groups, it leads to worse condition since there will be no more open discussion in the groups.

Entrepreneurial group with members of students who have passions on entrepreneurship, surely will motivate the members, as a place to share the best practice, experience and may avoid what went wrong.

2. Exposure to small business enterprise As Kuratko (2005) explained that students need the exposure to entrepreneurs who have experienced facing challenges and endured failures as their best practice.

Exposure to a small business enterprise hopefully will make students comprehend real condition and broaden their skill and experience about business, such as how to start, to manage, to solve the problem and the most important is to sustain in the business. At last, their experience can motivate them to handle situation whatever problem they face.

3. Building networking with entrepreneurs, business entity, government

It is as stated by Kuttim, Kallaste, Venesaar and Kiis (2014) in their research that students expect more on networking and coaching activities.

Networking will surely boost the development of students business since it may provide positive, successful best practice, specific knowledge or skill of entrepreneurship, as well as potential financial support. 


\section{References}

Akhuemonkhan, I. A. 2005. Modalities of Teaching Entrepreneurship in Technical Institution.

Eze, John F., Nwali, Anthony C. 2012. Capacity Building for Entrepreneurship Education: The Challenge for The Developing Nations. American Journal of Business Education (AJBE), pp. 401-408.

Fitriati, Rachma. 2012. Entrepreneurship Education: Toward Models in Several Indonesia's University. The $4^{\text {th }}$ International Conference on Indonesian Studies, pp 681-698. Bali.

Hisrich, R.D.1996. Entrepreneurship and intrapreneurship: methods of creating new companies that have an impact on the economic renaissance of an era, in entrepreneurship, intrapreneurship and venture capital. Lexington Books.

Kasali, Rhenald. 2010. Modul Kewirausahaan Untuk Program Strata 1. Rumah Perubahan.

Kuttim, Merle. Kallaste, Marianne. Venesaar, Urve. Kiis, Aino. 2014. Entrepreneurship Education at University Level and Students Entrepreneurial Intentions. Journal of Procedia - Social and Behavioral Sciences, pp 658-668.

Kuratko, Donald F. 2005. The Emergence of Entrepreneurship Education: Development, Tends and Challenges. Journal of Entrepreneurship Theory and Practice (ETP), pp 577597.

Kurya, U. L. 2006. Concept of Entrepreneurship and Types of Entrepreneurs, in Entrepeneurship Education for Vocational and Technical Students. Benchmark Publisher.

Kuswara, Heri. Strategi Perguruan Tinggi Mewujudkan Entrepreneurial Campus. Retrieved from http://www.dikti.go.id/strategi-perguruan-tinggi-mewujudkanentrepreneurial-campus/ at 9 January 2017.

Nwazor, J.C. 2012. Capacity Building, Entrepreneurship and Sustainable Development. Journal of Emerging Trends in Educational Research and Policy Studies (JETERAPS) pp. 51-54.

Philip, Kotler. 2000. Manajemen Pemasaran. Edisi Milenium Jilid 1\&2. Prenhalindo: Jakarta.

Zhou, Mansheng and Xu, Haixia. 2012. A Review of Entrepreneurship Education for College Students in China. Journal of Administrative Sciences, pp 82-94. 
